\title{
Dominant Advertisement Strategies in Iranian TV Commercials and their Cognitive Effect
}

\author{
Parvaneh Khosravizadeh*, Saeedeh Jafari Pazoki
}

Language and Linguistics Center, Sharif University of Technology, Azadi Avenue, 14588-89694, Tehran, Iran

Corresponding Author: Parvaneh Khosravizadeh, E-mail: khosravizadeh@sharif.edu

\section{ARTICLE INFO}

Article history

Received: July 26, 2017

Accepted: October 15, 2017

Published: January 05, 2018

Volume: 7 Issue: 1

Advance access: December 2017

Conflicts of interest: None

Funding: None

\begin{abstract}
Advertising strategies are some factors in the content and form of advertisements which are intended to have certain effects on ad viewers or potential customers. These effects could be defined as the kind of cognitive responses they are expected to elicit in their audiences. This study examined 39 Iranian TV commercials in seven product categories to identify the most dominant strategies used by the advertisers and investigated the effect of product type on the selection and use of these strategies. The results showed that Iranian TV commercials used a mixture of analytic and effective cognitive strategies among which "elaborating on the reasons to buy", "explaining the quality appeal" are the most favorite analytic based strategies and use of emotion and mood arising words is the most dominant affective based advertising method. The results also endorse significant effect of product type on types of strategies employed in the ads.
\end{abstract}

Key words: Communication, Advertisement Strategies, Cognition, TV Commercials, Cognitive Strategies

\section{INTRODUCTION}

Advertisements are everywhere and it is almost impossible to avoid them. We can consider advertisements as a piece of information which is processed by a potential consumer's perceptual as well as cognitive system. This process will create a mental representation which will generate a specific feeling and attitude toward a specific product and eventually it can result in a behavior which could possibly be purchasing that product (Harris, Sturm, Klassen \& Bechtold, 1986). As Fennis and Stroebe (2010) reported a typical person is exposed to 1000 ads a day. They further pointed out that in the majority of cases we are not paying direct attention to ads and they should struggle to attract attention and get into memory and stick in the mind. In this competition, advertisements try to be more effective through using appropriate strategies. It is important to analyze ads because as Cook (2001) mentioned, they have significant impact on our social life, environment and health both in positive and negative ways. When analyzing ads, we need to analyze them as discourse which means language and its context of use. According to Cook (2001), advertisement discourse not only encompasses the language but the music, picture, participants and other non-verbal elements combined with language to add to its meaning. Cook truly argued that if we ignore considering all the components involved in ad's discourse it may lead to misinterpretation of the ad message. In order to analyze advertising discourse we need to understand human cognition and the processes involved in receiving ad message and the effects it has on human cognition.

\section{Ads Categories}

Cook (2001) categorized ads based on different factors such as the medium in which they appear, the type of product they advertise and finally the strategies used in advertising. Since the focus of this paper is on TV advertisement, we skip the first classification criteria and briefly discuss the other two. According to Cook (2001), advertisements can be categorized based on types of good and services they advertise because different goods and services require different advertisement strategies. For example, the ad strategies used for a luxury good differ from those for advertising household necessities. Moreover, advertising techniques for selling a product is different from advertising for charities or political parties. The focus in this paper is on TV commercials which advertise different products or services. On the other hand, the other categorizing criterion is based on the strategies used in advertisements. Some advertisements use reason and some tickle. The former group uses reason for persuading customers to buy products and the latter arouse emotion, humor and mood for buying the product.

\section{Advertising Techniques}

Different advertisement techniques are used based on the product types, and the types of customers they targets at- based on their life style, socio economic class, point 
in the life cycle, age and personality types (Cook, 2001). Fennis and Stroebe (2010), on the other hand, divided the types of ad strategies into argument-based and affect-based appeals. They explained that the former type employs reason or argument and the latter uses emotion and feeling to convey their messages. They attribute the strategy choosing criteria to the type of product being advertised and the "involvement level" of the audience. As they maintained, the products that are chosen by the customers based on personal experiences, preferences and tastes are more likely to be advertised using affective method while durable and more expensive products such as a computer or washing machine are advertised using the rational based method. They further stated that affect-based messages require lower cognitive processing and as a result more appropriate for customers with lower involvement or motivation. A study done by Venkatraman, Marlino, Kardes and Sklar (1990) showed that consumers who are reluctant to be involved mentally and cognitively in the add communication are more likely to be affected by affective based ads while those who have the propensity to be engaged in the cognitive processing are affected by argument based ads. The question that may arise here is that why some customers may like to be more involved in ad messages while others do not. Fennis and Stroebe (2010) identified four stages through which consumers acquire, represent and encode advertising messages. These stages are 1) pre-attentive stage; in which customers do not pay direct attention to the ads, however they are influenced by the message 2) focal attention; in which the ad message is brought into conscious awareness. In this stage add properties such as its salience, novelty, use of humor, being emotionally interesting, using image provoking language and scene, and audience feature such as their motivation and intention and preferences are important factors for the ad to attract conscious attention, 3) comprehension; it is an effortful process in which the audience make inferences and judgement about the message, 4) elaborative reasoning; in which the audience is involved in active thinking and relates semantically represented stimulus to the previously stored schemata. Fennis and Stroebe (2010) stated that the degree of cognitive involvement of the audience in passing through these stages can be determined by factors such as the price of the product, and the effect that buying or having that product have on people's lives, and the goal or the motivation of the audience-for example if he is planning to buy a car. The second stage as Robinson (1998) stated can generate instant emotion unconsciously. Therefore, as Fennis and Stroebe (2010) concluded, in a situation that the advertisement does not have the potential to attract conscious attention and lead customers to the third and fourth stage, it uses emotion rising strategies to at least arouse some sort of emotional response. In this situation, negative response may even be more effective. One of the strongest emotional strategies used in ads is fear arousing technique introduced by Kardes (as cited in Fennis and Stroebe, 2010) which tries to persuade the customers for buying the product by referring to the risk of not having that specific product. Using pleasant and engaging music, beautiful scene, a good-looking model or celebrity or other pleasant events can associate positive feeling to a product being advertised through classical conditioning and generate positive attitude of the customers. Based on classical conditioning strategy, a neutral stimulus that is incapable of producing any particular emotional response is repeatedly associated with an emotional stimulus and gradually acquire the ability to arouse positive emotional response. On the other hand, if the customer is motivated enough to be involved in the third and second stage, ads can use more useful strategies which lead the customers' through more engaging cognitive processes. Different cognitive responses were identified in ads'. Fennis and Stroebe (2010) classified the customer response to cognitive response; affective response and behavioral response. In a similar classification, Chaudhuri and Buck (1995) explained, that consumer responses could be either analytic or affective. As they asserted some strategies are devised to stimulate analytic cognition while some others are expected to induce affective cognition. Based on this taxonomy, those advertisements that focus on the product information as its main content try to persuade the audiences through the process of attention, comprehension and consequently drawing an appropriate conclusion and finally storing the message in their memory based on the information and the facts provided by the advertisement about a certain product. Therefore, product information strategies are pertained to analytic cognition. On the other hand, some other advertisements use three types of strategies to trigger affective cognition. These strategies include spokesperson strategies which refers to those advertisements which show typical consumers, celebrities who express their content which a product and generate affective reaction based on the attitude of the audience toward that person. The other strategy of this type is mood arousal strategy which incorporates theories of conditioning in a sense that in these advertisements a product is repeatedly paired with a typical mood such as happiness, excitement, being healthy, friendship, romantic relationship, etc., to produce a positive affective response and form a positive image of the product. The other affective strategy is the status appeals strategy in which the advertisement show a reward or punishment because of using or not using a specific product in order to build up a belief about a product based on the emotional reaction. All different types of strategies explained here can employ linguistic, visual and auditory stimulus to elicit cognitive response in their audiences. Given that, it is interesting to know how Iranian televised advertisement employ these strategies and if certain product type based on the nature of the product and the certain group of people it aimed at affect the selection of analytic or affective strategies for advertising. Accordingly this research is aimed at answering 1) What are the dominant advertisement strategies employed by Iranian TV commercials in terms of the cognitive response they intent to elicit in their audiences, and 2) How product type affect the use of different cognitive response strategies in Iranian TV commercials. 


\section{METHODOLOGY}

In order to investigate dominant advertisement strategies in Iranian TV commercials a scale established by Chaudhuri and Buck (1995) were used with reported reliability of.93. This scale was slightly modified to evaluate the content and elements incorporated in Iranian TV commercials based on the cognitive response they intend to elicit and the devices they use to do so(Table 1).

Moreover, 39 TV commercials which were aired through Iranian TV channels during winter 2016 were se- lected. The ads were selected in a way that they include a variety of products and services including seven major product types: cars and related products, phone services, snacks and junk foods products, home appliances and furniture, hygiene products and cosmetics and washing and cleaning products.

All the selected advertisements were evaluated and the strategies used in the commercials were extracted based on the scale provided in Table 1 and analyzed statistically to investigate what is the dominant advertisement strategies used in Iranian TV commercials and how the product type or

Table 1. Advertisement strategies and related cognitive response types

\begin{tabular}{|c|c|c|c|}
\hline \multicolumn{2}{|l|}{ Cognitive response type } & & Code \\
\hline \multirow[t]{11}{*}{ Analytics cognitive response } & Production information strategy & Comparing the brand with other brands & 1 \\
\hline & & Elaborating on the reasons to buy & 2 \\
\hline & & Explaining quality appeal & 3 \\
\hline & & Explaining the ingredients & 4 \\
\hline & & $\begin{array}{l}\text { Explaining the price appeal or economy in use } \\
\text { appeal }\end{array}$ & 5 \\
\hline & & Explaining time/labor saving appeal & 6 \\
\hline & & Explaining life made easier appeal & 7 \\
\hline & & Explaining environment appeal & 8 \\
\hline & & Explaining warranty appeal & 9 \\
\hline & & Explaining relief from a problem or pain & 10 \\
\hline & & Explaining research results & 11 \\
\hline \multirow[t]{24}{*}{ Affective cognitive response } & Spokes person & Use of celebrity & 12 \\
\hline & & Use of expert sources & 13 \\
\hline & & Use of attractive spokesperson & 14 \\
\hline & Mood arousal trategy & Use of romantic relationship & 15 \\
\hline & & Use of friendship & 16 \\
\hline & & Use of family atmosphere & 17 \\
\hline & & Use of nostalgia & 18 \\
\hline & & Use of nature/animals/birds & 19 \\
\hline & & Use of travel & 20 \\
\hline & & Use of sport activity & 21 \\
\hline & & Use of excitement & 22 \\
\hline & & Use of good health and fitness & 23 \\
\hline & & Use of leisure activity & 24 \\
\hline & & Use of artistic activity & 25 \\
\hline & & Use of enjoyment and pleasure & 26 \\
\hline & & Use of children & 27 \\
\hline & & Use of young people & 28 \\
\hline & & Use of people having good time & 29 \\
\hline & & Use of emotion and mood arising words & 30 \\
\hline & & Use of music and song & 31 \\
\hline & Status appeals strategy & Picturing desirable life style & 32 \\
\hline & & Use of affluent setting & 33 \\
\hline & & Receiving gift or award & 34 \\
\hline & & Others approval/disapproval & 35 \\
\hline
\end{tabular}


the target audience affect use of different strategies. A table is provided in the appendix with detailed description of the advertisement analysis.

\section{RESULTS}

Descriptive statistics showed that from all the strategies used in 39 ads under investigation "Elaborating on the reasons to buy" (48\%) and "Explaining the quality appeal" (43\%) and from analytic cognitive strategy type and "Use of emotion and mood arising words" (36\%) from affective cognitive category were the most frequent strategies across all ad categories. Table 2 shows other most frequent ad strategies ordered from the most frequent to the least frequent.

Table 3 (See Appendix 1) shows the mean scores of the strategies used in each category. Among the high frequency strategies in different product categories; "Elaborating on the reasons to buy" and "Explain quality appeal" for washing and cleaning products and use of music and song for snack and junk food were the most frequent strategies. Other frequent strategies are highlighted in the table.

In order to answer the second research question a oneway between-groups analysis of variance was conducted to investigate the effect of product type on the type of strategies used in advertisements. In this research, ads about 7 categories of products including cars and related products, home appliance, mobile operator, snacks

Table 2. Most frequent ad strategies in Iranian TV commercials

\begin{tabular}{llc}
\hline No. & Ad strategies & Frequency (\%) \\
\hline 1 & Elaborating on the reasons to buy & 48 \\
2 & Explaining quality appeal & 43 \\
3 & Use of emotion and mood arising & 36 \\
& words & 30 \\
4 & Use of nature/animals/birds & 28 \\
5 & Use of children & 23 \\
6 & Use of young people & 25 \\
7 & Use of music and song & \\
\hline
\end{tabular}

and junk food, food products, hygiene and washing and cleaning products were examined. The results showed that there is a significant difference between strategies used for different product type: $F(39)=3.1, p=.014$. Among the examined categories, washing and cleaning products ads employ the highest analytic cognitive response strategies $(\mathrm{M}=.23, \mathrm{SD}=.07)$ followed by hygiene products $(\mathrm{M}=.10, \mathrm{SD}=.08$ and cars and related products $(\mathrm{m}=.1, \mathrm{SD}=.03)$.

In terms of the affective cognitive response strategies there was not a significant difference among the product types; $\mathrm{F}(39)=1.34, \mathrm{P}=.2$. Descriptive data showed that among the ads categories mobile operators used the most cognitive response strategies $(\mathrm{M}=.11, \mathrm{SD}=.07)$ followed by snacks and junk food products $(\mathrm{M}=.95, \mathrm{SD}=.06)$.

\section{DISCUSSION AND CONCLUSION}

The purpose of this study was to explore the cognitive strategies used in Iranian TV commercials. As the results showed, Iranian TV commercials used variety of strategies among which "Elaborating on the reasons to buy" and Explaining the quality appeal" from the analytic cognitive strategies were the most popular and approximately half of the ads under investigation used these strategies either by themselves or in combination with other strategies. "Use of emotion and mood arising words" was the other highly frequent strategy from the affective cognitive category. Product type was an important factor for determining the strategy types. For example, snacks and junk foods are mostly advertised using affective strategies and no analytic cognitive strategy was used in this type of ad. Since children are the main target audience for snacks and junk foods, they are mostly advertised through "Use of leisure activity", "Use of enjoyment and pleasure", "Use of children", "Use of people having good time", "Use of music and song". These findings show that children are expected to be less focused on the deep cues and are less engaged in the elaboration of the message (Loken, 2006). Accordingly, mood and emotion arising technique is the most favored strategy in this type of ads. Mobile operators' ads are the other group of ads with strong inclination toward affective

Table 4. Mean score of different product categories in Analytic cognitive strategies

\begin{tabular}{|c|c|c|c|c|c|c|c|c|}
\hline & \multirow[t]{2}{*}{$\mathbf{N}$} & \multirow[t]{2}{*}{ Mean } & \multirow[t]{2}{*}{$\begin{array}{l}\text { Standard } \\
\text { deviation }\end{array}$} & \multirow[t]{2}{*}{ Standard error } & \multicolumn{2}{|c|}{$\begin{array}{l}95 \% \text { confidence } \\
\text { interval for mean }\end{array}$} & \multirow[t]{2}{*}{ Minimum } & \multirow[t]{2}{*}{ Maximum } \\
\hline & & & & & $\begin{array}{l}\text { Lower } \\
\text { bound }\end{array}$ & $\begin{array}{l}\text { Upper } \\
\text { bound }\end{array}$ & & \\
\hline Car and related product & 5 & 0.1000 & 0.03423 & 0.01531 & 0.0575 & 0.1425 & 0.06 & 0.13 \\
\hline Home appliance & 11 & 0.0966 & 0.10218 & 0.03081 & 0.0279 & 0.1652 & 0.00 & 0.31 \\
\hline Mobile operator & 3 & 0.0417 & 0.03608 & 0.02083 & -0.0480 & 0.1313 & 0.00 & 0.06 \\
\hline Snack and Junk food & 3 & 0.0000 & 0.00000 & 0.00000 & 0.0000 & 0.0000 & 0.00 & 0.00 \\
\hline Food product & 7 & 0.0446 & 0.09350 & 0.03534 & -0.0418 & 0.1311 & 0.00 & 0.25 \\
\hline Hygiene & 6 & 0.1042 & 0.08539 & 0.03486 & 0.0146 & 0.1938 & 0.00 & 0.19 \\
\hline Washing and cleaning & 4 & 0.2344 & 0.07864 & 0.03932 & 0.1092 & 0.3595 & 0.13 & 0.31 \\
\hline Total & 39 & 0.0913 & 0.09602 & 0.01538 & 0.0602 & 0.1225 & 0.00 & 0.31 \\
\hline
\end{tabular}


Table 5. Different product categories in Analytic cognitive strategies

\begin{tabular}{lccccc}
\hline ANOVA & & & & & \\
\hline & Sum of squares & df & Mean square & F & Sig. \\
\hline Between groups & 0.131 & 6 & 0.022 & 0.193 \\
Within groups & 0.219 & 32 & 0.007 & \\
Total & 0.350 & 38 & & \\
\hline
\end{tabular}

Table 6. Mean score of different product categories in affective cognitive strategies

\begin{tabular}{|c|c|c|c|c|c|c|c|c|}
\hline & \multirow[t]{2}{*}{$\overline{\mathbf{N}}$} & \multirow[t]{2}{*}{ Mean } & \multirow[t]{2}{*}{$\begin{array}{l}\text { Standard } \\
\text { deviation }\end{array}$} & \multirow[t]{2}{*}{ Standard error } & \multicolumn{2}{|c|}{$\begin{array}{l}95 \% \text { confidence } \\
\text { interval for mean }\end{array}$} & \multirow[t]{2}{*}{ Minimum } & \multirow[t]{2}{*}{ Maximum } \\
\hline & & & & & $\begin{array}{l}\text { Lower } \\
\text { bound }\end{array}$ & $\begin{array}{l}\text { Upper } \\
\text { bound }\end{array}$ & & \\
\hline Car and related product & 5 & 0.0254 & 0.02407 & 0.01077 & -0.0045 & 0.0553 & 0.00 & 0.06 \\
\hline Home appliance & 11 & 0.0700 & 0.06480 & 0.01954 & 0.0265 & 0.1135 & 0.00 & 0.18 \\
\hline Mobile operator & 3 & 0.1190 & 0.07054 & 0.04073 & -0.0562 & 0.2943 & 0.06 & 0.20 \\
\hline Snack and Junk food & 3 & 0.0952 & 0.06349 & 0.03666 & -0.0625 & 0.2530 & 0.03 & 0.16 \\
\hline Food product & 7 & 0.0544 & 0.01800 & 0.00680 & 0.0378 & 0.0711 & 0.03 & 0.08 \\
\hline Hygiene & 6 & 0.0595 & 0.06836 & 0.02791 & -0.0122 & 0.1313 & 0.00 & 0.15 \\
\hline Washing and cleaning & 4 & 0.0327 & 0.05540 & 0.02770 & -0.0554 & 0.1209 & 0.00 & 0.12 \\
\hline Total & 39 & 0.0618 & 0.05647 & 0.00904 & 0.0435 & 0.0801 & 0.00 & 0.20 \\
\hline
\end{tabular}

Table 7. Different product categories in affective cognitive strategies

\begin{tabular}{lccccc}
\hline & $\begin{array}{c}\text { Sum of } \\
\text { squares }\end{array}$ & df & $\begin{array}{c}\text { Mean } \\
\text { square }\end{array}$ & F & Sig. \\
\hline Between groups & 0.024 & 6 & 0.004 & 1.340 & 0.268 \\
Within groups & 0.097 & 32 & 0.003 & & \\
Total & 0.121 & 38 & & & \\
\hline
\end{tabular}

cognitive strategy. This propensity can be explained by the nature of the product and the potential customers who are young people and teenagers. For mobile operators like snacks and junk food, mood and emotion arising techniques are the most popular. These findings are in line with Fennis and Stroebe (2010), prediction that those products which are chosen based on personal experiences, preferences and tastes are more likely to be advertised using affective method. The advertisers do not expected high involvement of their potential customers for cognitive processing of these ads' messages. Therefore, they draw on mood arising techniques to get their message across. It seems that advertisers draw on Loken's (2006) idea that "mood affect judgement, being in a positive mood can increase customer preferences for products". Advertisers of the products such as junk foods which are not healthy may prefer to prevent their audiences to be engaged in analytic elaboration of the message. Keller, Lipkus, \& Rimer, (2002) maintained that people in positive mood are less likely to become engaged in analytic processing while people in negative mood are more inclined to be engaged in analytic and effortful processing.

On the other hand, car products and home appliance ads are more inclined to use analytic cognitive strategies. Car and related products are less likely to rely on their customers' mood and emotion to buy their products and they expect high cognitive involvement on the part of their customers. Accordingly, cars and related products advertisers acquire the lowest mean among other products for using affective cognitive strategies. Home appliances and furniture on the other hand which has similar features as cars and related products are mostly advertised through analytic techniques rather than affective techniques. It is consistent with Cook (2001) and Fennis and Stroebe (2010) prediction that the ad strategies used for a luxury, durable and more expensive products are more analytic and rational based. Hygiene products and cosmetics and washing and cleaning products mostly used analytic based advertising methods. The rationale underlies such choice could be the importance of these products for people's health and that people are expected to buy these products based on a reason rather than pure emotion.

On the whole, type of the cognitive processes that the consumers engage themselves in, depends on their motivation and the nature of the message they receive. This interaction will eventually result in shaping a specific attitude toward a specific product which can result in persuading the audience to purchase the product.

\section{REFERENCES}

Chaudhuri, A., \& Buck, R. (1995). Affect, reason, and persuasion advertising strategies that predict affective and analytic-cognitive responses. Human Communication Research, 21(3), 422-441.

Cook, G. (2001). The discourse of advertising. London: Routledge. 
Fennis, B. M., \& Stroebe, W. (2010). The psychology of advertising. USA: Psychology Press.

Harris, R. J., Sturm, R. E., Klassen, M. L., \& Bechtold, J. I. (1986). Language in advertising: A psycholinguistic approach. Current Issues and Research in Advertising, 9(1-2), 1-26.

Keller, P. A., Lipkus, I. M., \& Rimer, B. K. (2002). Depressive realism and health risk accuracy: The negative consequences of positive mood. Journal of Consumer Research, 29(1), 57-69.
Loken, B. (2006). Consumer psychology: categorization, inferences, affect, and persuasion. Annu. Rev. Psychol., 57, 453-485.

Robinson, M. D. (1998). Running from William James' bear: A review of preattentive mechanisms and their contributions to emotional experience. Cognition \& Emotion, 12(5), 667-696.

Venkatraman, M. P., Marlino, D., Kardes, F. R., \& Sklar, K. B. (1990). The interactive effects of message appeal and individual differences on information processing and persuasion. Psychology \& Marketing, 7(2), 85-96.

\section{APPENDIX 1}

Table 3. Mean score of ad strategies used in different ad categories

\begin{tabular}{|c|c|c|c|c|c|c|c|c|}
\hline $\mathbf{N}$ & Strategies & $\begin{array}{l}\text { Car and } \\
\text { related } \\
\text { products }\end{array}$ & $\begin{array}{c}\text { Home } \\
\text { appliances } \\
\text { \& furniture }\end{array}$ & $\begin{array}{c}\text { Mobile } \\
\text { operators }\end{array}$ & $\begin{array}{c}\text { Snacks } \\
\text { and junk } \\
\text { foods }\end{array}$ & $\begin{array}{c}\text { Food } \\
\text { products }\end{array}$ & $\begin{array}{c}\text { Hygiene } \\
\text { products \& } \\
\text { cosmetics }\end{array}$ & $\begin{array}{l}\text { Washing } \\
\text { and } \\
\text { cleaning } \\
\text { products }\end{array}$ \\
\hline 1 & $\begin{array}{l}\text { Comparing the brand } \\
\text { with other brands }\end{array}$ & 0.00 & 0.09 & 0.00 & 0.00 & 0.14 & 0.00 & 0.25 \\
\hline 2 & $\begin{array}{l}\text { Elaborating on the } \\
\text { reasons to buy }\end{array}$ & 0.60 & 0.36 & 0.67 & 0.00 & 0.29 & 0.67 & 1.00 \\
\hline 3 & $\begin{array}{l}\text { Explaining quality } \\
\text { appeal }\end{array}$ & 0.60 & 0.45 & 0.00 & 0.00 & 0.14 & 0.67 & 1.00 \\
\hline 4 & $\begin{array}{l}\text { Explaining the } \\
\text { ingredients }\end{array}$ & 0.00 & 0.00 & 0.00 & 0.00 & 0.00 & 0.00 & 0.25 \\
\hline 5 & $\begin{array}{l}\text { Explaining the price } \\
\text { appeal or economy in } \\
\text { use appeal }\end{array}$ & 0.40 & 0.18 & 0.00 & 0.00 & 0.00 & 0.00 & 0.25 \\
\hline 6 & $\begin{array}{l}\text { Explaining time/labor } \\
\text { saving appeal }\end{array}$ & 0.00 & 0.00 & 0.00 & 0.00 & 0.00 & 0.00 & 0.50 \\
\hline 7 & $\begin{array}{l}\text { Explaining life made } \\
\text { easier appeal }\end{array}$ & 0.00 & 0.00 & 0.00 & 0.00 & 0.00 & 0.00 & 0.25 \\
\hline 8 & $\begin{array}{l}\text { Explaining } \\
\text { environment appeal }\end{array}$ & 0.00 & 0.09 & 0.00 & 0.00 & 0.00 & 0.00 & 0.00 \\
\hline 9 & $\begin{array}{l}\text { Explaining warranty } \\
\text { appeal }\end{array}$ & 0.00 & 0.18 & 0.00 & 0.00 & 0.00 & 0.00 & 0.00 \\
\hline 10 & $\begin{array}{l}\text { Explaining relief from } \\
\text { a problem or pain }\end{array}$ & 0.00 & 0.09 & 0.00 & 0.00 & 0.14 & 0.33 & 0.25 \\
\hline 11 & $\begin{array}{l}\text { Explaining research } \\
\text { results }\end{array}$ & 0.00 & 0.09 & 0.00 & 0.00 & 0.00 & 0.00 & 0.00 \\
\hline 12 & Use of celebrity & 0.00 & 0.00 & 0.33 & 0.00 & 0.00 & 0.00 & 0.00 \\
\hline 13 & Use of expert sources & 0.00 & 0.09 & 0.00 & 0.00 & 0.00 & 0.00 & 0.00 \\
\hline 14 & $\begin{array}{l}\text { Use of attractive } \\
\text { spokesperson }\end{array}$ & 0.00 & 0.00 & 0.00 & 0.00 & 0.00 & 0.00 & 0.00 \\
\hline 15 & $\begin{array}{l}\text { Use of romantic } \\
\text { relationship }\end{array}$ & 0.00 & 0.00 & 0.00 & 0.00 & 0.00 & 0.00 & 0.00 \\
\hline 16 & Use of friendship & 0.00 & 0.00 & 0.33 & 0.33 & 0.14 & 0.00 & 0.00 \\
\hline 17 & $\begin{array}{l}\text { Use of family } \\
\text { atmosphere }\end{array}$ & 0.20 & 0.09 & 0.33 & 0.00 & 0.57 & 0.17 & 0.25 \\
\hline 18 & Use of nostalgia & 0.00 & 0.09 & 0.00 & 0.00 & 0.00 & 0.00 & 0.00 \\
\hline
\end{tabular}


Table 3. (Continued)

\begin{tabular}{|c|c|c|c|c|c|c|c|c|}
\hline $\mathbf{N}$ & Strategies & $\begin{array}{c}\text { Car and } \\
\text { related } \\
\text { products }\end{array}$ & $\begin{array}{c}\text { Home } \\
\text { appliances } \\
\text { \& furniture }\end{array}$ & $\begin{array}{c}\text { Mobile } \\
\text { operators }\end{array}$ & $\begin{array}{c}\text { Snacks } \\
\text { and junk } \\
\text { foods }\end{array}$ & $\begin{array}{c}\text { Food } \\
\text { products }\end{array}$ & $\begin{array}{c}\text { Hygiene } \\
\text { products \& } \\
\text { cosmetics }\end{array}$ & $\begin{array}{c}\text { Washing } \\
\text { and } \\
\text { cleaning } \\
\text { products }\end{array}$ \\
\hline 19 & $\begin{array}{l}\text { Use of nature/animals/ } \\
\text { birds }\end{array}$ & 0.40 & 0.18 & 0.33 & 0.33 & 0.29 & 0.67 & 0.00 \\
\hline 20 & Use of travel & 0.20 & 0.00 & 0.00 & 0.33 & 0.14 & 0.00 & 0.00 \\
\hline 21 & Use of sport activity & 0.00 & 0.09 & 0.67 & 0.33 & 0.14 & 0.00 & 0.00 \\
\hline 22 & Use of excitement & 0.00 & 0.09 & 0.00 & 0.33 & 0.00 & 0.00 & 0.00 \\
\hline 23 & $\begin{array}{l}\text { Use of good health and } \\
\text { fitness }\end{array}$ & 0.00 & 0.00 & 0.00 & 0.00 & 0.29 & 0.00 & 0.00 \\
\hline 24 & Use of leisure activity & 0.00 & 0.09 & 0.00 & 0.67 & 0.00 & 0.00 & 0.00 \\
\hline 25 & Use of artistic activity & 0.00 & 0.00 & 0.00 & 0.00 & 0.00 & 0.17 & 0.00 \\
\hline 26 & $\begin{array}{l}\text { Use of enjoyment and } \\
\text { pleasure }\end{array}$ & 0.00 & 0.00 & 0.33 & 0.67 & 0.43 & 0.00 & 0.00 \\
\hline 27 & Use of children & 0.20 & 0.18 & 0.67 & 0.67 & 0.43 & 0.17 & 0.00 \\
\hline 28 & Use of young people & 0.00 & 0.09 & 0.67 & 0.33 & 0.29 & 0.33 & 0.25 \\
\hline 29 & $\begin{array}{l}\text { Use of people having } \\
\text { good time }\end{array}$ & 0.00 & 0.00 & 0.00 & 0.67 & 0.14 & 0.00 & 0.00 \\
\hline 30 & $\begin{array}{l}\text { Use of emotion and } \\
\text { mood arising words }\end{array}$ & 0.60 & 0.27 & 0.67 & 0.33 & 0.29 & 0.33 & 0.25 \\
\hline 31 & Use of music and song & 0.00 & 0.36 & 0.00 & 1.00 & 0.29 & 0.17 & 0.00 \\
\hline 32 & $\begin{array}{l}\text { Picturing desirable life } \\
\text { style }\end{array}$ & 0.00 & 0.00 & 0.00 & 0.00 & 0.17 & 0.25 & 0.00 \\
\hline 33 & Use of affluent setting & 0.00 & 0.18 & 0.33 & 0.00 & 0.00 & 0.00 & 0.00 \\
\hline 34 & $\begin{array}{l}\text { Receiving gift or } \\
\text { award }\end{array}$ & 0.00 & 0.18 & 0.00 & 0.00 & 0.00 & 0.00 & 0.00 \\
\hline 35 & $\begin{array}{l}\text { Others approval/ } \\
\text { disapproval }\end{array}$ & 0.00 & 0.09 & 0.00 & 0.00 & 0.00 & 0.17 & 0.00 \\
\hline
\end{tabular}

APPENDIX 2

\begin{tabular}{|c|c|c|c|c|}
\hline Brand & $\begin{array}{l}\text { Product } \\
\text { category }\end{array}$ & Analytics cognitive & Affective cognitive & $\begin{array}{l}\text { Mood and emotion } \\
\text { rising words }\end{array}$ \\
\hline Saipa group & $\begin{array}{l}\text { Car sales } \\
\text { festival }\end{array}$ & $\begin{array}{l}\text { Explain the price appeal or } \\
\text { economy in use appeal }\end{array}$ & & \\
\hline $\begin{array}{l}\text { MVM X } 33 \text { S } \\
\text { Modiran Khodro }\end{array}$ & Car & $\begin{array}{l}\text { Elaborating on the reasons to buy } \\
\text { Showing quality appeal }\end{array}$ & $\begin{array}{l}\text { Use of nature } \\
\text { Use of emotional words }\end{array}$ & $\begin{array}{l}\text { Superlative adjective: } \\
\text { best selling } \\
\text { Comfort, joy, ideal }\end{array}$ \\
\hline $\begin{array}{l}\text { Chery } \\
\text { MVM } \\
\text { Modiran Khodro }\end{array}$ & Car & $\begin{array}{l}\text { Elaborating on the reasons to buy } \\
\text { Showing/explaining quality appeal }\end{array}$ & & $\begin{array}{l}\text { Modern } \\
\text { State of the art } \\
\text { Strong } \\
\text { Safe }\end{array}$ \\
\hline $\begin{array}{l}\text { MVM } 550 \\
\text { Modiran Khodro }\end{array}$ & Car Leasing & $\begin{array}{l}\text { Explain the price appeal or } \\
\text { economy in use appeal }\end{array}$ & $\begin{array}{l}\text { Use of nature } \\
\text { Use of travel } \\
\text { Use of family atmosphere } \\
\text { Use of children }\end{array}$ & \\
\hline Caspian Car Engine Oil & $\begin{array}{l}\text { Car engine } \\
\text { oil }\end{array}$ & $\begin{array}{l}\text { Elaborating on the reasons to buy } \\
\text { Showing/explaining quality appeal }\end{array}$ & & $\begin{array}{l}\text { State of the art } \\
\text { The best }\end{array}$ \\
\hline
\end{tabular}


(Continued)

\begin{tabular}{|c|c|c|c|c|}
\hline Brand & $\begin{array}{l}\text { Product } \\
\text { category }\end{array}$ & Analytics cognitive & Affective cognitive & $\begin{array}{l}\text { Mood and emotion } \\
\text { rising words }\end{array}$ \\
\hline $\begin{array}{l}\text { LG } \\
\text { Door-in-door } \\
\text { refrigerator }\end{array}$ & $\begin{array}{l}\text { Home } \\
\text { applia3nce }\end{array}$ & $\begin{array}{l}\text { Elaborating on the reasons to buy } \\
\text { Showing/explaining quality appeal } \\
\text { Explain environment (energy } \\
\text { saving) appeal }\end{array}$ & $\begin{array}{l}\text { Use of family atmosphere } \\
\text { Use of children }\end{array}$ & \\
\hline Samsung TV set & $\begin{array}{l}\text { Home } \\
\text { appliance }\end{array}$ & Explain warranty appeal & $\begin{array}{l}\text { Use of children } \\
\text { Use of music } \\
\text { Use of young people } \\
\text { Use of excitement } \\
\text { Use of sport activity } \\
\text { Affluent setting } \\
\text { Use of leisure activity }\end{array}$ & $\begin{array}{l}\text { Amazing } \\
\text { Shocking } \\
\text { Marvel } \\
\text { Inspiring moments } \\
\text { Enthusiasm } \\
\text { Strength } \\
\text { A leap }\end{array}$ \\
\hline $\begin{array}{l}\text { Ilia Steel } \\
\text { oven }\end{array}$ & $\begin{array}{l}\text { Home } \\
\text { appliance }\end{array}$ & $\begin{array}{l}\text { Elaborating on the reasons to buy } \\
\text { Showing/explaining quality appeal } \\
\text { Explain warranty appeal }\end{array}$ & Use of music & \\
\hline $\begin{array}{l}\text { Iran Radiator } \\
\text { Water heater }\end{array}$ & $\begin{array}{l}\text { Home } \\
\text { appliance }\end{array}$ & & $\begin{array}{l}\text { Use of music and song } \\
\text { Use of nostalgia } \\
\text { Others approval }\end{array}$ & Warmth \\
\hline $\begin{array}{l}\text { Alborz steel kitchen } \\
\text { hood }\end{array}$ & $\begin{array}{l}\text { Home } \\
\text { appliance }\end{array}$ & $\begin{array}{l}\text { Explain research results } \\
\text { Explain relief from a problem or } \\
\text { pain } \\
\text { Elaborating on the reasons to buy } \\
\text { Explain quality appeal } \\
\text { comparing }\end{array}$ & Use of expert sources & \\
\hline Sani electric heater & $\begin{array}{l}\text { Home } \\
\text { appliance }\end{array}$ & $\begin{array}{l}\text { Elaborating on the reasons to buy } \\
\text { Explain quality appeal }\end{array}$ & & $\begin{array}{l}\text { Warmth } \\
\text { Pleasant }\end{array}$ \\
\hline Melal Furniture & $\begin{array}{l}\text { Home } \\
\text { appliance }\end{array}$ & $\begin{array}{l}\text { Showing/explaining quality } \\
\text { appeal } \\
\text { Explain the price appeal or } \\
\text { economy in use appeal }\end{array}$ & & \\
\hline $\begin{array}{l}\text { PI GI MA } \\
\text { Furniture }\end{array}$ & $\begin{array}{l}\text { Home } \\
\text { appliance }\end{array}$ & $\begin{array}{l}\text { Explain the price appeal or } \\
\text { economy in use appeal }\end{array}$ & Affluent setting & \\
\hline Tafte Carpet & $\begin{array}{l}\text { Home } \\
\text { Appliance }\end{array}$ & & $\begin{array}{l}\text { Use of nature (flower) } \\
\text { Use of emotional words }\end{array}$ & $\begin{array}{l}\text { Unique } \\
\text { Eye catching } \\
\text { Beautiful } \\
\text { Different } \\
\text { Noble } \\
\text { Perdurable } \\
\text { Good feeling } \\
\text { Reliability } \\
\text { Satisfaction }\end{array}$ \\
\hline Gheitaran Carpet & $\begin{array}{l}\text { Home } \\
\text { appliance }\end{array}$ & & $\begin{array}{l}\text { Use of music and song } \\
\text { Use of emotional and } \\
\text { mood arising words }\end{array}$ & $\begin{array}{l}\text { Unique } \\
\text { Varied } \\
\text { Beautiful } \\
\text { Glory } \\
\text { Love } \\
\text { Global } \\
\text { Iranian }\end{array}$ \\
\hline KWC Faucet & $\begin{array}{l}\text { Home } \\
\text { appliance }\end{array}$ & & $\begin{array}{l}\text { Receiving gift or award } \\
\text { Affluent setting } \\
\text { Use of nature (flowers) }\end{array}$ & \\
\hline
\end{tabular}


(Continued)

\begin{tabular}{|c|c|c|c|c|}
\hline Brand & $\begin{array}{l}\text { Product } \\
\text { category }\end{array}$ & Analytics cognitive & Affective cognitive & $\begin{array}{l}\text { Mood and emotion } \\
\text { rising words }\end{array}$ \\
\hline $\begin{array}{l}\text { Raitel } \\
\text { Mobile Operator }\end{array}$ & $\begin{array}{l}\text { Mobile } \\
\text { operator }\end{array}$ & Elaborating on the reasons to buy & $\begin{array}{l}\text { Use of children } \\
\text { Use of sport activity } \\
\text { Use of friendship } \\
\text { Use of young people } \\
\text { Use of nature } \\
\text { use of emotion and mood } \\
\text { arising words }\end{array}$ & $\begin{array}{l}\text { Indefinite } \\
\text { Laughter } \\
\text { Nostalgia } \\
\text { Effort } \\
\text { Success } \\
\text { Friendship } \\
\text { Memory }\end{array}$ \\
\hline $\begin{array}{l}\text { Hamrahe Aval } \\
\text { Mobile Operator }\end{array}$ & $\begin{array}{l}\text { Mobile } \\
\text { operator }\end{array}$ & Elaborating on the reasons to buy & $\begin{array}{l}\text { Use of children } \\
\text { Use of family atmosphere } \\
\text { Use of enjoyment and } \\
\text { pleasure } \\
\text { use of mood and emotion } \\
\text { arising words }\end{array}$ & $\begin{array}{l}\text { Good time } \\
\text { Accompany } \\
\text { Trust } \\
\text { Feeling safe }\end{array}$ \\
\hline Hamrahe Aval & $\begin{array}{l}\text { Mobile } \\
\text { Operator }\end{array}$ & & $\begin{array}{l}\text { Use of sport activity } \\
\text { Use of young people } \\
\text { Affluent setting } \\
\text { Use of sport celebrities }\end{array}$ & \\
\hline Shiba & $\begin{array}{l}\text { Snack and } \\
\text { Junk food }\end{array}$ & & $\begin{array}{l}\text { Use of music } \\
\text { Use of mood and emotion } \\
\text { arising words }\end{array}$ & Happiness \\
\hline Lina & $\begin{array}{l}\text { Snack and } \\
\text { Junk food }\end{array}$ & & $\begin{array}{l}\text { Use of music and song } \\
\text { Use of children } \\
\text { Use of young people } \\
\text { Use of friendship } \\
\text { Use of nature } \\
\text { Use of travel } \\
\text { Use of sport activity } \\
\text { Use of leisure activity } \\
\text { Use of enjoyment and } \\
\text { pleasure } \\
\text { Use of people having } \\
\text { good time }\end{array}$ & \\
\hline $\begin{array}{l}\text { Babana } \\
\text { Cake }\end{array}$ & $\begin{array}{l}\text { Snack and } \\
\text { junk food }\end{array}$ & & $\begin{array}{l}\text { Use of leisure activity } \\
\text { Use of music and song } \\
\text { Use of enjoyment and } \\
\text { pleasure } \\
\text { Use of children } \\
\text { Use of people having } \\
\text { good time } \\
\text { Use of excitement }\end{array}$ & \\
\hline $\begin{array}{l}\text { Roozaneh } \\
\text { Cheese }\end{array}$ & $\begin{array}{l}\text { Food } \\
\text { produc } 5 \mathrm{t}\end{array}$ & & Use of music & $\begin{array}{l}\text { Soft } \\
\text { Tender }\end{array}$ \\
\hline $\begin{array}{l}\text { Delpazir } \\
\text { Ketchup sauce }\end{array}$ & $\begin{array}{l}\text { Food } \\
\text { product }\end{array}$ & & $\begin{array}{l}\text { Use of family atmosphere } \\
\text { Use of children } \\
\text { Use of enjoyment and } \\
\text { pleasure }\end{array}$ & $\begin{array}{l}\text { Delicious } \\
\text { Healthy }\end{array}$ \\
\hline $\begin{array}{l}\text { Sabah } \\
\text { Cheese }\end{array}$ & $\begin{array}{l}\text { Food } \\
\text { product }\end{array}$ & & $\begin{array}{l}\text { Use of family atmosphere } \\
\text { Use of good health and } \\
\text { fitness } \\
\text { Use of enjoyment and } \\
\text { pleasure } \\
\text { Use of children } \\
\text { Use of people having } \\
\text { good time }\end{array}$ & Healthy \\
\hline
\end{tabular}


(Continued)

\begin{tabular}{|c|c|c|c|c|}
\hline Brand & $\begin{array}{l}\text { Product } \\
\text { category }\end{array}$ & Analytics cognitive & Affective cognitive & $\begin{array}{l}\text { Mood and emotion } \\
\text { rising words }\end{array}$ \\
\hline $\begin{array}{l}\text { Oila } \\
\text { Cooking oil }\end{array}$ & $\begin{array}{l}\text { Food } \\
\text { product }\end{array}$ & $\begin{array}{l}\text { Comparing the brand with other } \\
\text { brands } \\
\text { Elaborating on the reasons to buy } \\
\text { Explain quality appeal } \\
\text { Explain relief from a problem or } \\
\text { pain }\end{array}$ & $\begin{array}{l}\text { Fear arousing technique } \\
\text { Use of good health and } \\
\text { fitness }\end{array}$ & \\
\hline Azar Makaron & $\begin{array}{l}\text { Food } \\
\text { product }\end{array}$ & Elaborating on the reasons to buy & $\begin{array}{l}\text { Use of music } \\
\text { Use of children } \\
\text { Use of family atmosphere } \\
\text { Use of enjoyment and } \\
\text { pleasure }\end{array}$ & \\
\hline Lipton Tea Bag & $\begin{array}{l}\text { Food } \\
\text { product }\end{array}$ & & $\begin{array}{l}\text { Use of nature } \\
\text { Use of young people } \\
\text { use of sport activity } \\
\text { use of friendship }\end{array}$ & \\
\hline Captain Tea & $\begin{array}{l}\text { Food } \\
\text { product }\end{array}$ & & $\begin{array}{l}\text { Use of family atmosphere } \\
\text { Use of young people } \\
\text { Use of travel } \\
\text { Use of nature }\end{array}$ & $\begin{array}{l}\text { Life } \\
\text { Memorable } \\
\text { Taste }\end{array}$ \\
\hline $\begin{array}{l}\text { Sehhat } \\
\text { Shampoo }\end{array}$ & $\begin{array}{l}\text { Hygiene } \\
\text { products }\end{array}$ & $\begin{array}{l}\text { Elaborating on the reasons to buy } \\
\text { Explain quality appeal } \\
\text { Explain relief from a problem or } \\
\text { pain }\end{array}$ & $\begin{array}{l}\text { Use of nature } \\
\text { Use of music }\end{array}$ & \\
\hline $\begin{array}{l}\text { My } \\
\text { Hand Cream }\end{array}$ & $\begin{array}{l}\text { Hygiene } \\
\text { products }\end{array}$ & & $\begin{array}{l}\text { Use of young people } \\
\text { Use of nature } \\
\text { Use of artistic activity } \\
\text { Others approval } \\
\text { Use of emotion or mood } \\
\text { Arising words }\end{array}$ & $\begin{array}{l}\text { Youth } \\
\text { Young } \\
\text { Four season }\end{array}$ \\
\hline $\begin{array}{l}\text { Parjak } \\
\text { Shampoo }\end{array}$ & $\begin{array}{l}\text { Hygiene } \\
\text { products }\end{array}$ & $\begin{array}{l}\text { Elaborating on the reasons to buy } \\
\text { Explain quality appeal }\end{array}$ & Use of nature & \\
\hline $\begin{array}{l}\text { Ave } \\
\text { Liquid soap }\end{array}$ & $\begin{array}{l}\text { Hygiene } \\
\text { products }\end{array}$ & & $\begin{array}{l}\text { Use of children } \\
\text { Use of family atmosphere } \\
\text { Use of nature } \\
\text { Use of emotion or mood } \\
\text { arising words } \\
\text { Picturing desirable life } \\
\text { style }\end{array}$ & $\begin{array}{l}\text { Fresh } \\
\text { Clean } \\
\text { Variety of odour }\end{array}$ \\
\hline $\begin{array}{l}\text { Dove } \\
\text { Shampoo }\end{array}$ & $\begin{array}{l}\text { Hygiene } \\
\text { products }\end{array}$ & $\begin{array}{l}\text { Elaborating on the reasons to buy } \\
\text { Explain quality appeal } \\
\text { Explain relief from a problem or } \\
\text { pain }\end{array}$ & & \\
\hline Signal toothpaste & $\begin{array}{l}\text { Hygiene } \\
\text { products }\end{array}$ & $\begin{array}{l}\text { Elaborating on the reasons to buy } \\
\text { Explain quality appeal }\end{array}$ & Use of young people & \\
\hline $\begin{array}{l}\text { Taj } \\
\text { detergent }\end{array}$ & $\begin{array}{l}\text { Washing } \\
\text { and } \\
\text { cleaning } \\
\text { products }\end{array}$ & $\begin{array}{l}\text { Elaborating on the reasons to buy } \\
\text { Explain quality appeal }\end{array}$ & $\begin{array}{l}\text { Use of young people } \\
\text { Use of emotion and mood } \\
\text { Arising words } \\
\text { Picturing desirable life } \\
\text { style }\end{array}$ & $\begin{array}{l}\text { Quality } \\
\text { Bright } \\
\text { White }\end{array}$ \\
\hline $\begin{array}{l}\text { Prill } \\
\text { Dish washer detergent }\end{array}$ & $\begin{array}{l}\text { Washing } \\
\text { and } \\
\text { cleaning } \\
\text { products }\end{array}$ & $\begin{array}{l}\text { Elaborating on the reasons to buy } \\
\text { Explain quality appeal } \\
\text { Explain time/labor saving appeal } \\
\text { Explain life made easier appeal }\end{array}$ & Use of family atmosphere & \\
\hline
\end{tabular}


(Continued)

\begin{tabular}{|c|c|c|c|c|}
\hline Brand & $\begin{array}{l}\text { Product } \\
\text { category }\end{array}$ & Analytics cognitive & Affective cognitive & $\begin{array}{l}\text { Mood and emotion } \\
\text { rising words }\end{array}$ \\
\hline $\begin{array}{l}\text { Damastus whitenning } \\
\text { liquid }\end{array}$ & $\begin{array}{l}\text { Washing } \\
\text { and } \\
\text { cleaning } \\
\text { products }\end{array}$ & $\begin{array}{l}\text { Elaborating on the reasons to buy } \\
\text { Explain quality appeal } \\
\text { Comparing the brand with other } \\
\text { brands } \\
\text { Explain the price appeal or } \\
\text { economy in use appeal } \\
\text { Explain time/labor saving appeal }\end{array}$ & & \\
\hline Home care & $\begin{array}{l}\text { Washing } \\
\text { and } \\
\text { cleaning } \\
\text { products }\end{array}$ & $\begin{array}{l}\text { Elaborating on the reasons to buy } \\
\text { Explain quality appeal } \\
\text { Explain the ingredients } \\
\text { Explain relief from a problem or } \\
\text { pain }\end{array}$ & & \\
\hline
\end{tabular}

